\author{
Military Technical College \\ Kobry El-Kobbah, \\ Cairo, Egypt
}

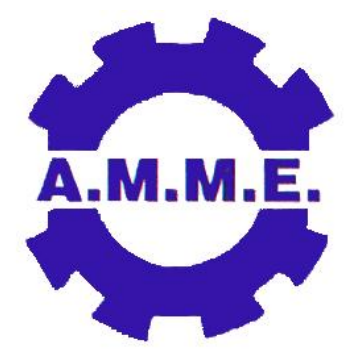

14th International Conference on Applied Mechanics and Mechanical Engineering.

\title{
Thermoeconomic Optimization for A Co-Generation Plant Based on Productive Structure Technique
}

By
A. H.Gomaa*
A. F. El-Dib"
I. H.Afefy

\begin{abstract}
:
In this paper, thermoeconomic optimization method based on productive structure technique is applied to a co-generation plant. The co-generation plant consists of a water-tube boiler, steam turbine, feed-water pump, deaerator, condenser, process-heaters and condensate tank. Global optimization of the whole plant is carried out based on separated local optimizations of different main components. The local optimization technique requires thermoeconomic and mathematical models. The results show that the boiler efficiency increases from $81 \%$ for the initial (normal) operating conditions to $90.48 \%$ for the optimum ones. On the other hand, the process-air heater efficiency increases from $63 \%$ to $64.5 \%$ for the optimum operating conditions. Moreover, as a global result, about $11.53 \%$ of the total product cost for all components of the plant is reduced when using optimum operating conditions other than normal ones.
\end{abstract}

\section{Keywords:}

Thermoeconomic Optimization; Productive Structure; Product Cost 
* Professor of Industrial Engineering - Faculty of Engineering -Benha University

** Professor of Mechanical Power Engineering- Faculty of Engineering - Cairo University

*** Lecture of Industrial Engineering - Faculty of Engineering- Fayoum University

\section{Introduction:}

The present study has been performed for a practical co-generation plant. The plant provides electrical and thermal energies to Egyptian Minerals and Salts Company (EMISAL), EL-Fayoum, Egypt. The main product of the company is sodium sulphate unhydrous. Thermoeconomic optimization technique of specific process unit variables is the suitable tool to minimize final product costs and save resource energy [1]. Moreover, the optimization process is based on analytic methodologies that determine optimal or near-optimal solutions by calculating exergy losses and entropy production cost in different system components [2]. The following aspects show the necessity of applying optimization procedures in the design and operation of the steam system[3, 4]:-

- $\quad$ Increasing the quality and capacity of the system while reducing cost in order to be competitive

- $\quad$ Saving energy and material resources.

- $\quad$ Best operating point at each instant time such as temperature, pressure and mass flow rate.

A thermoeconomic model represents mathematically the productive structure of a plant, which is a graphical representation of resource distribution. The flows in the productive structure describe the productive relations between all the components based on physical structure. The thermoeconomic model can be logically defined by the following procedures [5]:

i.A physical model of the plant is built first

ii.Productive structure is applied

Flow streams entering the system components are usually its fuel, and the flow stream leaving the system components is its product $[4,6,7,8]$.

The block diagram describes the relation between the input to the optimization mathematical model (objective function and constraints) and output from the model (minimum product costs of all components and maximum efficiency). To optimize the steam systems, mathematical model, optimization algorithm and Lingo program are chosen as the suitable tools. The block diagram for the optimization mathematical model is shown in Fig.1. 


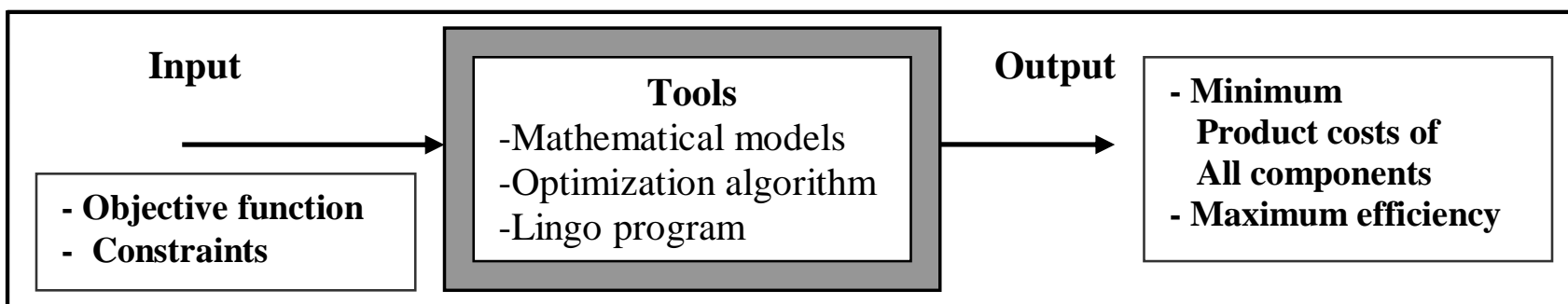

Figure( 1): Block diagram for optimization mathematical.

The physical model of the analyzed co-generation plant is shown in Fig.2. The cogeneration plant provides electrical energy and heat to electric grid and process-heaters in installation. Steam generated in the boiler is used for both operating the steam turbine to produce the electric power output and supplying the process steam to heat process brine and process air. Condensate leaving both process-brine and process-air heaters is collected in the condensate tank, and then supplied to the deaerator throygh two condensate pumps. Feed water is fed to the boiler through the feed-water pump. Some steam is taken directly from the boiler where its pressure is reduced through a throttling valve (Thv7) and its temperature is controlled through a desuperheater (Desup8) to heat air in the process-air heater. The process-brine heater uses steam extracted from he lowpressure section of the turbine, whose temperature is controlled in another desupqrheater (Desup10). Dearator (DRT5) is very important to remove the non-condensable gqses via the deaeration process.

\section{Productive Structure Technique:}

The productive structure (Fig. 3) represents the productive interaction among the different components of the plant, and it is a tool that helps to calculate the cost of the interral flows of the system. The inlet arrows to the components represent the resources consumed in the component and the outlet arrows correspond to the products. Bifurcations, alsp called branches (b1), and junctions (J1) are fictitious devices that represent the fuel and products.

\subsection{Thermoeconomic Analysis:}

Thermoeconomic analysis is used in technical and economic evaluation of the plant Also, it is used to perform a diagnostic of the steam systems. The thermeconomid model encompasses the definition of a productive structure function (product) for each cormponent and resource that each one needs to consume (fuel) in order to achieve the production objective. The product cost equations and the costs of the main flow streams of the plant are presented in Table 1. Equations of the capital cost for the plant are presented $n$ Table 2 .

$$
\begin{aligned}
& \dot{Z}=Z^{*} \varphi \\
& \text { And, } \\
& \varphi=\left(\mathrm{FCR}^{*} \Phi\right) /\left(3.6^{*} 10^{5 *} \mathrm{n}\right)
\end{aligned}
$$
is the maintenance factor; FCR is the annual fixed charge rate percent; $n$ is the number of operating hours per year, and $Z$ is the capital cost. The following standard valups have been considered: FCR=18.2 \%; $\Phi=1.06 ; n=8000$ h/y [11]. 


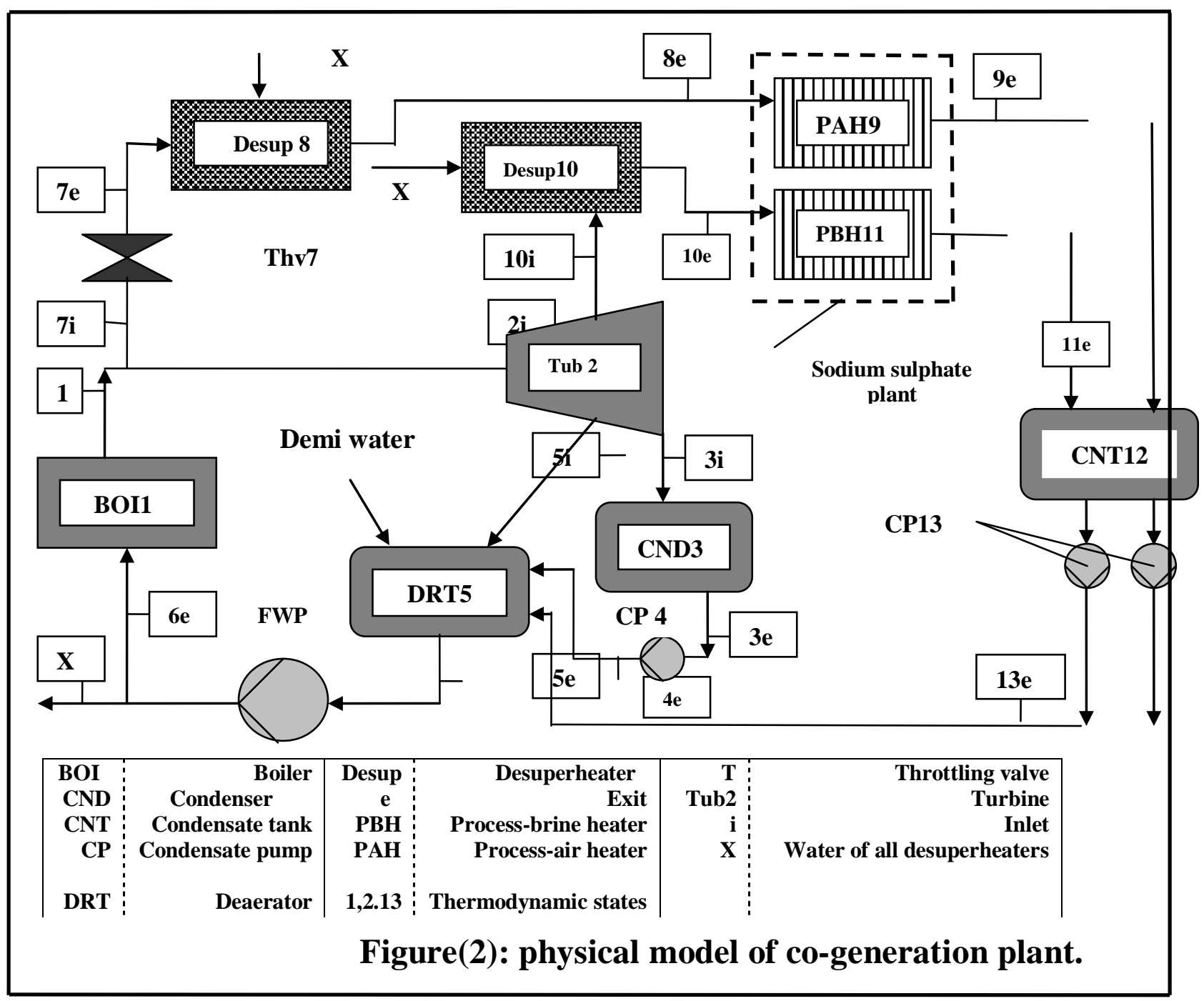

Table (1): Product cost equations applied in the productive structure [1]

\begin{tabular}{|c|c|c|}
\hline Device No. & Device symbol & Product cost equations \\
\hline 1 & Boiler (BOI1) & $\mathrm{C}_{1}=\left(\mathrm{C}_{1}{ }^{*} \mathrm{C}_{\mathrm{f}}+\mathrm{N}_{1}{ }^{*} \mathrm{CS}+\mathrm{Z}_{1}{ }^{*} \mathrm{\varphi}\right) / \mathrm{B}_{1}$ \\
\hline 2 & Turbine (Tub2) & $\mathrm{C}_{2}=\left(\mathrm{B}_{2}{ }^{*} \mathrm{Ca}+\mathrm{N}_{2}{ }^{*} \mathrm{Cs}+\mathrm{Z}_{2}{ }^{*} \varphi\right) / \mathrm{W}_{2}$ \\
\hline 3 & Condenser (CND3) & $\mathrm{C}_{3}=\left(\mathrm{B}_{3}{ }^{*} \mathrm{C} a+\mathrm{Z}_{3}^{*} \varphi\right) / \mathrm{N}_{3}$ \\
\hline 4 & Condensate Pump (CP4) & $\mathrm{C}_{4}=\left(\mathrm{W}_{4}{ }^{*} \mathrm{cb}+\mathrm{N}_{4}{ }^{*} \mathrm{cs}+\mathrm{Z}_{4}{ }^{*} \varphi\right) / \mathrm{B}_{4}$ \\
\hline 5 & Dearator (DRT5) & $\mathrm{C}_{5}=\left(\mathrm{F}_{5}{ }^{*} \mathrm{ca}+\mathrm{N}_{5}{ }^{*} \mathrm{cs}+\mathrm{Z}_{5}{ }^{*} \varphi\right) / \mathrm{B}_{5}$ \\
\hline 6 & Feed-Water Pump (FWP6) & $\mathrm{C}_{6}=\left(\mathrm{W}_{6}{ }^{*} \mathrm{cb}+\mathrm{N}_{6}{ }^{*} \mathrm{cs}+\mathrm{Z}_{6}{ }^{*} \varphi\right) / \mathrm{B}_{6}$ \\
\hline 7 & Throttling Valve (Thv7) & $\mathrm{c}_{7}=\left(\mathrm{F}_{7}^{*} \mathrm{ca}+\mathrm{N}_{7}{ }^{*} \mathrm{cS}+\mathrm{Z}_{7}^{*} \varphi\right) / \mathrm{B}_{7}$ \\
\hline 8 & Desuperheater (Desup8) & $\mathrm{C}_{8}=\left(\mathrm{F}_{8}{ }^{*} \mathrm{Ca}+\mathrm{N}_{8}{ }^{*} \mathrm{CS}+\mathrm{Z}_{8}{ }^{*} \varphi\right) / \mathrm{B}_{8}$ \\
\hline 8 & Process-Air Heater (PAH9) & $\mathrm{C}_{9}=\left(\mathrm{F}_{9}{ }^{*} \mathrm{Ca}+\mathrm{N}_{9}{ }^{*} \mathrm{CS}+\mathrm{Z}_{9}{ }^{*} \varphi\right) / \mathrm{B}_{9}$ \\
\hline 10 & Desuperheater (Desup10) & $c_{10}=\left(F_{10}{ }^{*} \mathrm{ca}+\mathrm{N}_{10}{ }^{*} \mathrm{cs}+\mathrm{Z}_{10}{ }^{*} \varphi\right) / \mathrm{B}_{10}$ \\
\hline 11 & $\begin{array}{l}\text { Process-Brine } \\
\text { Heater(PBH11) }\end{array}$ & $\mathrm{c}_{11}=\left(\mathrm{F}_{11}{ }^{*} \mathrm{c} \mathrm{c}+\mathrm{N}_{11}{ }^{*} \mathrm{c} C+\mathrm{Z}_{11}{ }^{*} \varphi\right) / \mathrm{B}_{11}$ \\
\hline
\end{tabular}


Proceeding of the 14th AMME Conference, 25 -27 May $2010 \quad$ Paper MP - $2 \quad 5$

\begin{tabular}{|c|c|c|}
\hline $\begin{array}{l}12 \\
13 \\
14\end{array}$ & $\begin{array}{l}\text { Condensate Tank (CNT12) } \\
\text { Condensate Pump (CP13) } \\
\text { Junction (J1) }\end{array}$ & 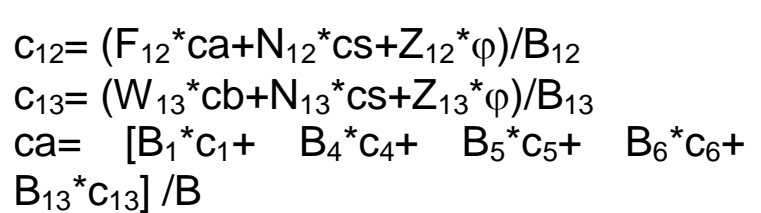 \\
\hline
\end{tabular}




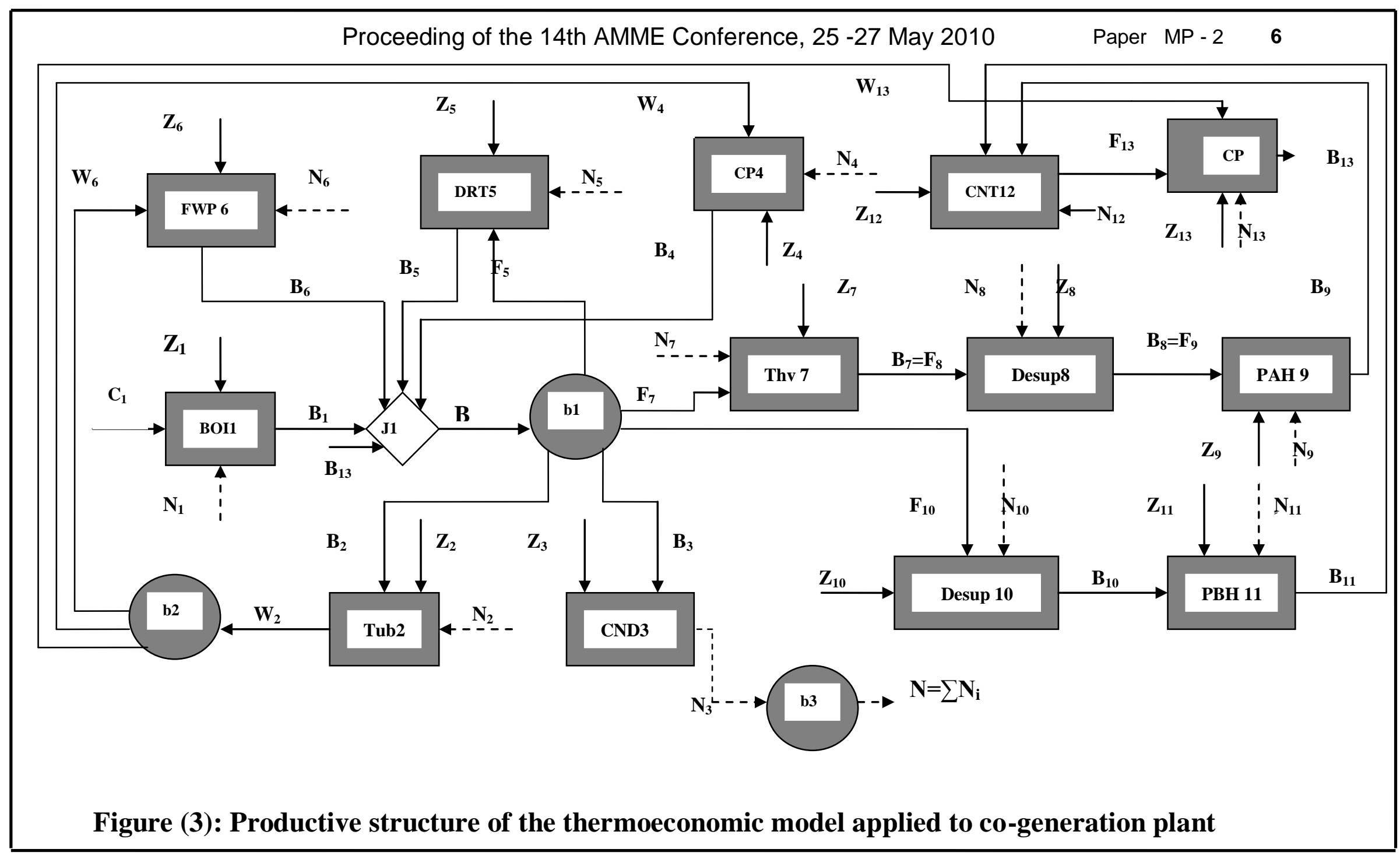


Table (2): Equations of the capital cost for the plant

\begin{tabular}{|c|c|c|c|c|}
\hline $\begin{array}{l}\text { Device } \\
\text { No. }\end{array}$ & $\begin{array}{l}\text { Device } \\
\text { symbol }\end{array}$ & \multicolumn{2}{|l|}{ Capital cost equations } & Ref. \\
\hline 1 & BOI1 & $\begin{array}{l}\dot{Z}_{1}=\left(a_{11}\right)\left(g_{1 \eta}\right)\left(g_{1 T}\right)\left(g_{1 p}\right)\left(Y_{1}\right)^{0.8} \\
g_{1 \eta}=1+\left[\left(1-\eta_{r}\right) /\left(1-\eta_{1}\right)\right]^{7} \\
g_{1 T}=1+5 \exp \left[\left(T_{1}-866\right) / 10.42\right]\end{array}$ & $\begin{array}{l}a_{11}=360 \$ / k W \\
g_{1 p}=\exp \left[\left(P_{1}-28\right) / 150\right] \\
Y_{1}=M_{\text {st }}\left[h_{\text {in }}-h_{\text {out }}\right]\end{array}$ & [10] \\
\hline 2 & Tub2 & \multicolumn{2}{|c|}{$\begin{aligned} Z_{2}= & 3000^{*}\left[1+5 \exp \left(\left(T_{2}-866\right) / 10.42\right)^{*}\left[1+\left(\left(1-\eta_{\mathrm{r}}\right) /(1-\right.\right.\right. \\
& \left.\left.\left.\left.\eta_{2}\right)\right)^{3}\right]^{*} W_{2}\right)^{0.782} \\
W_{2}= & \left.\left.\left.\left.M_{2} h_{2}\right)_{i}-M_{3} h_{3}\right)_{i}-M_{10} h_{10}\right)_{i}-M_{5} h_{5}\right)_{i} \\
\eta_{2}= & \left(h_{2 i}-h_{5 i}\right) /\left(h_{2 i}-h_{5 i}\right)_{s}\end{aligned}$} & {$[1]$} \\
\hline 3 & CND3 & \multicolumn{2}{|c|}{$\begin{aligned} Z_{3}= & {\left[1 /\left(T_{0}-e_{3}\right)\right]^{*} 217^{*}\left[0.247+1 /\left(3.24{ }^{*}\left(V_{3}\right)^{0.8}\right)\right]^{*} } \\
& \ln \left[1 /\left(1-e_{3}\right)+138\right]+\left[1 /\left(1-\eta_{3}\right)\right]{ }^{*} N_{3}{ }^{*} 50\end{aligned}$} & {$[1]$} \\
\hline $4,6,13$ & $\mathrm{CP}$ & \multicolumn{2}{|c|}{$\mathrm{Z}=378^{*} \mathrm{~B}^{0.71 *}\left[1+\left(\left(1-\eta_{\mathrm{r}}\right) /(1-\eta)\right)^{3}\right]$} & [1] \\
\hline 5 & DRT5 & $Z_{5}=10.4 \hat{Y} 5$ & $-\Sigma \mathrm{M} \mathrm{h})_{\text {out }}$ & [10] \\
\hline 9,11 & \begin{tabular}{|l|}
$\mathrm{PAH} 9$, \\
$\mathrm{PBH} 11$
\end{tabular} & \multicolumn{2}{|c|}{$\begin{aligned} \mathrm{Z}= & 0.02 * 3.3^{*} \mathrm{Q}{ }^{*}\left(\Delta \mathrm{P}_{\mathrm{s}}\right)^{-0.04 *} \mathrm{abs}(1 /(\mathrm{TTD}-1))^{-0.1 *} \\
& \left(\Delta \mathrm{P}_{\mathrm{t}}\right)^{-0.08 *}{ }^{-0.000}\end{aligned}$} & {$[1]$} \\
\hline 12 & \begin{tabular}{|l|} 
CNT12 \\
\end{tabular} & $Z_{12}=10.4 \hat{Y}_{12}$ & $\overline{M ~ h)_{\text {in }}-\Sigma(\mathrm{M} \mathrm{h})_{\text {out }}}$ & {$[10]$} \\
\hline
\end{tabular}

\section{Optimization Mathematical Model:}

The mathematical model is a set of non-linear algebraic equations and can be logically defined by the following procedures:

Objective function equation

Constraints equation

The purpose of the mathematical model is to use generated simplified performance equations to describe the impact of the operating conditions and cost parameters on the steam systems performance. Also, these models describe the economic framework of the production facility. An optimization problem is called a problem of quadratic programming, if it consists of a quadratic objective function and inequality constraints.

\subsection{Boiler:}

The modeling system for boiler is presented in Fig. 4. The steam product cost depends on operating and economic parameters $\left(\mathrm{P}_{1}, \mathrm{~T}_{1}, \mathrm{M}_{1}, \mathrm{M}_{\mathrm{f}}\right.$ and cs $)$. Minimization of the cost rate $\left(\mathrm{c}_{1}\right)$ of the steam generation from boiler is selected as the optimization objective function:- 


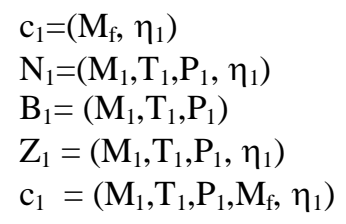

Input independent variable $\left(\mathrm{M}_{1}, \mathrm{~T}_{1}, \mathrm{P}_{1}, \mathrm{M}_{\mathrm{f}}, \eta_{1}\right)$

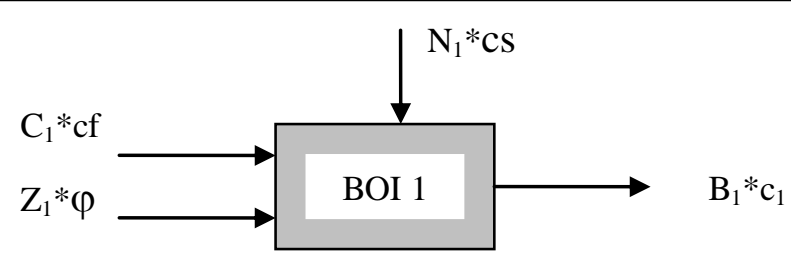

Any change of the input variable will change $\left(c_{1}, B_{1}\right)$
Output variable

$\longrightarrow\left(\mathrm{c}_{1}, \mathrm{~B}_{1}\right)$

Figure( 4): Water-tube boiler modeling

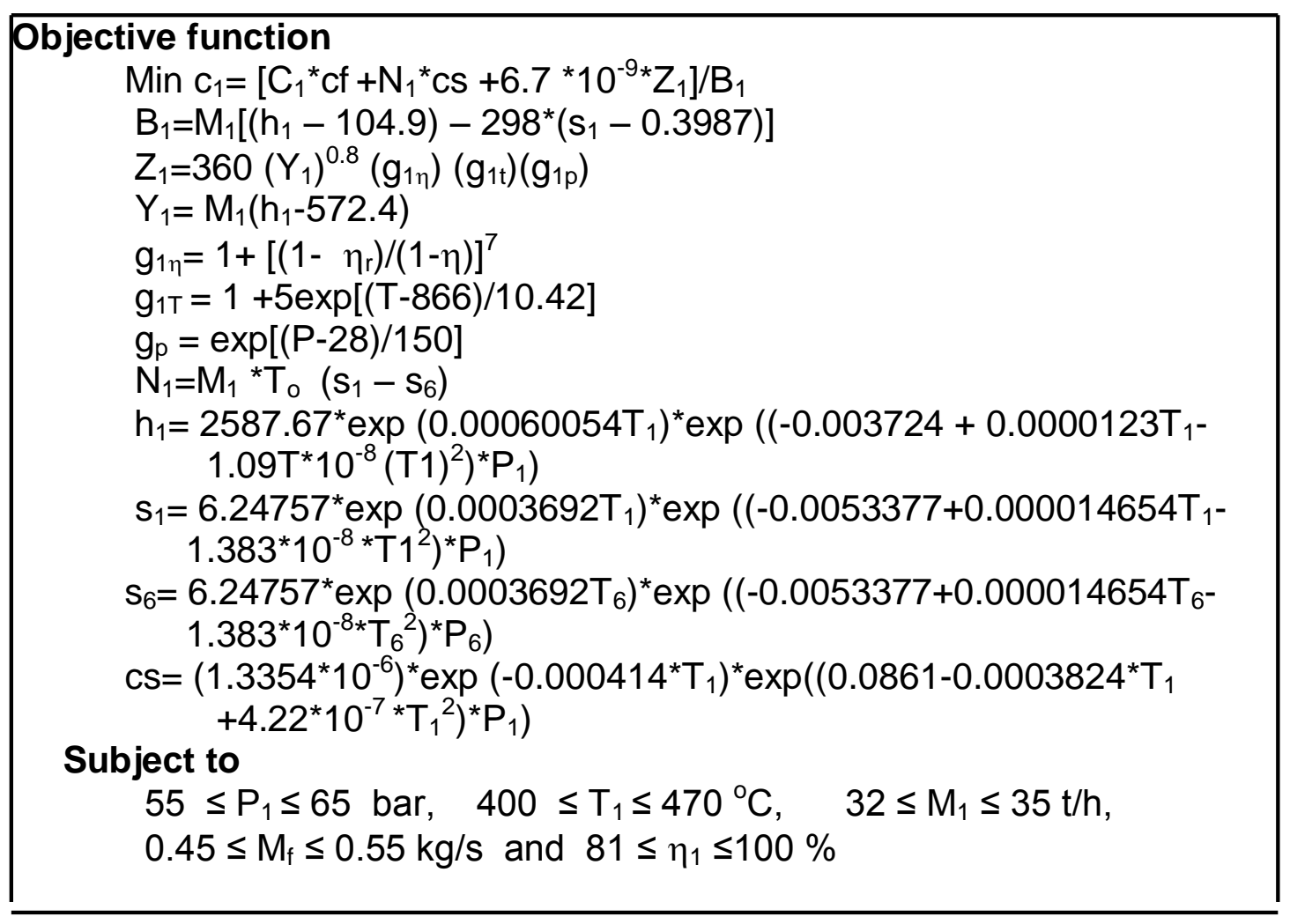

\section{2 Turbine:}

The modeling system for the studied steam turbine is presented in Fig. 5. This model shows the cost rate of the electric energy product $\left(\mathrm{c}_{2}\right)$ depends on physical and economic parameters $\left(\mathrm{T}_{10 \mathrm{i}}, \mathrm{M}_{2 \mathrm{i}}, \mathrm{M}_{10 \mathrm{i}}, \eta_{2}\right.$, ca and cs ). Moreover, minimization of the cost rate of the electric energy product from turbine is selected as the optimization objective function:- 


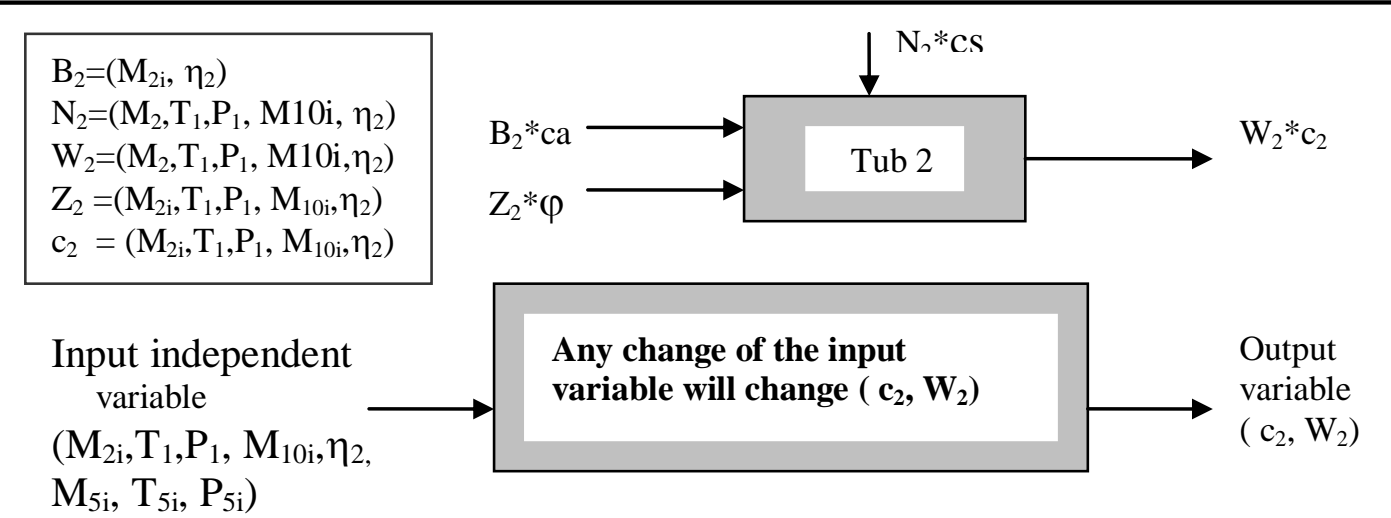

Figure (5): Steam turbine modeling

\section{Objective function}

$$
\begin{aligned}
& \text { Min } \mathrm{C}_{2}=\left[\mathrm{B}_{2}{ }^{*} \mathrm{Ca}+0.733^{*} 10^{-6 *} \mathrm{~N}_{2}+6.7{ }^{*} 10^{-9 *} \mathrm{Z}_{2}\right] / \mathrm{W}_{2} \\
& \mathrm{~B}_{2}=\mathrm{M}_{2}\left[\left(\mathrm{~h}_{2}-104.9\right)-298^{*}\left(\mathrm{~s}_{2}-0.3987\right)\right] \\
& \mathrm{N}_{2}=\mathrm{T}_{0}{ }^{*}\left(\mathrm{M}_{3}{ }^{*} S_{3 i}+\mathrm{M}_{10 \mathrm{i}}{ }^{*} \mathrm{~S}_{10 \mathrm{i}}+\mathrm{M}_{5 i}{ }^{*} \mathrm{~S}_{5 i}-\mathrm{M}_{2 i}{ }^{*} \mathrm{~S}_{2 i}\right) \\
& \left.Z_{2}=3000^{*}\left[1+5 \exp \left(\left(T_{2}-866\right) / 10.42\right)\right)^{*}\left[1+\left(\left(1-\eta_{r}\right) /\left(1-\eta_{2}\right)\right)^{3}\right]^{*} W_{2}\right)^{0.782} \\
& \mathrm{~h}_{2}=2587.67^{*} \exp \left(0.00060054 \mathrm{~T}_{2 \mathrm{i}}\right)^{*} \exp \left(\left(-0.003724+0.0000123 \mathrm{~T}_{2 \mathrm{i}^{-}}\right.\right. \\
& \left.\left.1.09 \mathrm{~T}^{*} 10^{-8} \mathrm{~T}_{2 \mathrm{i}}{ }^{2}\right)^{*} \mathrm{P}_{2 \mathrm{i}}\right) \\
& \mathrm{s}_{2}=6.24757^{*} \exp \left(0.0003692 \mathrm{~T}_{2 \mathrm{i}}\right)^{*} \exp \left(\left(-0.0053377+0.000014654 \mathrm{~T}_{2 \mathrm{i}^{-}}\right.\right. \\
& \left.\left.1.383^{*} 10^{-8}{ }^{*} \mathrm{~T}_{2 \mathrm{i}}{ }^{2}\right)^{*} \mathrm{P}_{2 \mathrm{i}}\right) \\
& \mathrm{h}_{5 \mathrm{i}}=2456.32^{*} \exp \left(0.0007579^{*} \mathrm{~T}_{5 \mathrm{i}}\right) \\
& \mathrm{S}_{5 \mathrm{i}}=6.2462^{*}\left(0.00065717^{*} \mathrm{~T}_{5 \mathrm{i}}\right) \\
& \left.\left.\left.\left.W_{2}=M_{2} h_{2}\right)_{i}-M_{3} h_{3}\right)_{i}-M_{10} h_{10}\right) i-M_{5} h_{5}\right)_{i} \\
& \eta_{2}=\left(h_{2 i}-h_{3 i}\right) /\left(h_{2 i}-h_{3 i}\right)_{s} \\
& \mathrm{ca}=\left(9.56193^{*} 10^{-6}\right)^{*} \exp \left(-0.004906^{*} \mathrm{~T}_{10 \mathrm{i}}\right)
\end{aligned}
$$

\section{Subject to}

$180 \leq \mathrm{T}_{10 \mathrm{i}} \leq 200{ }^{\circ} \mathrm{C}, \quad 29 \leq \mathrm{M}_{2 \mathrm{i}} \leq 31 \mathrm{t} / \mathrm{h}, \quad 75.58 \leq \eta_{2} \leq 100 \%$ and $11 \leq M_{10 i} \leq 14 t / h, 180 \leq T_{5 i} \leq 200^{\circ} \mathrm{C}, M_{5 i} \& P_{5 i}=$ constant

\subsection{Process-Air Heater (PAH9):}

The modeling system for process-air heater (PAH9) is presented in Fig. 6 . This model shows the product cost of process-air heater depending on operating parameters $\left(T_{9}, P_{9}, M_{9}, M_{a}\right.$ and $\eta_{9}$ ) and economic parameters (cs and $\mathrm{ca}$ ). Moreover, minimization of the product cost of process-air heater (PAH9) is selected as the optimization objective function:- 


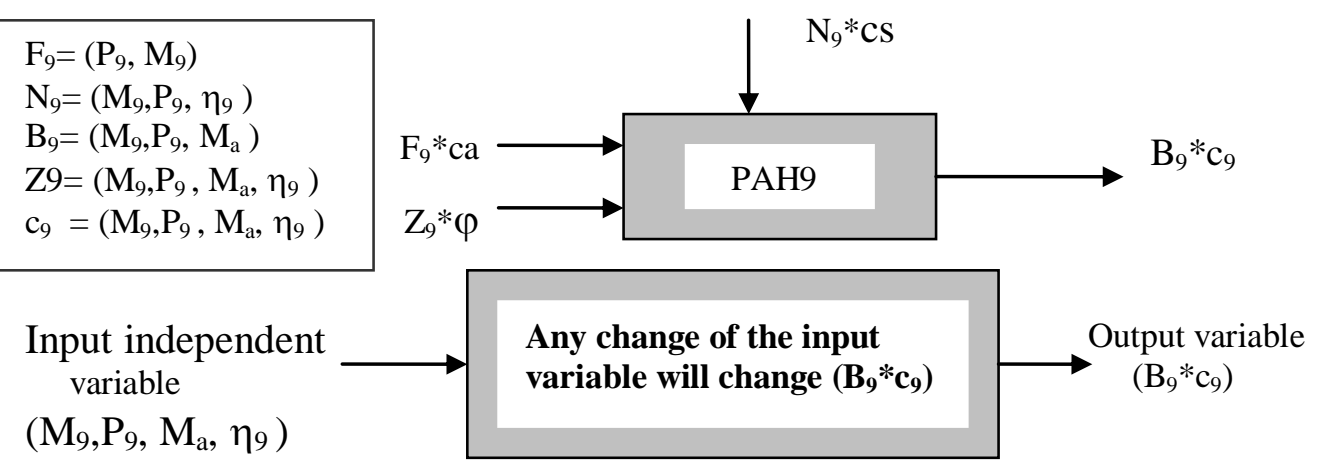

Figure (6): Process-air heater modeling

$$
\begin{aligned}
& \text { Objective function } \\
& \text { Min } \mathrm{C}_{9}=\left(\mathrm{F}_{9}{ }^{*} \mathrm{Ca}+\mathrm{N}_{9}{ }^{*} \mathrm{Cs}+6.7{ }^{*} 10^{-9 *} \mathrm{Z}_{9}\right) / \mathrm{B}_{9} \\
& \mathrm{~B}_{9}=\mathrm{M}_{9 \mathrm{e}}\left[\left(\mathrm{h}_{9 \mathrm{e}}-104.9\right)-298^{*}\left(\mathrm{~s}_{9 \mathrm{e}}-0.3987\right)\right] \\
& \mathrm{F}_{9}=\mathrm{M}_{9}\left(\left(\mathrm{~h}_{9 \mathrm{i}}-104.3\right)-298\left(\mathrm{~S}_{9 \mathrm{i}}-0.3987\right)\right) \\
& \mathrm{N}_{9}=\mathrm{M}_{9 \mathrm{i}}{ }^{*} \mathrm{~T}_{0}\left(\mathrm{~S}_{9 \mathrm{e}}-\mathrm{S}_{9 \mathrm{i}}\right) \\
& Z_{9}=\left(1000^{*} 0.02^{*} 3.3^{*} Q_{9}\right) /\left((0.4)^{0.04 *} \operatorname{abs}(1 / \text { TTD9-5) })^{0.1}(0.7)^{0.08}\right) \quad \text { [1] } \\
& \mathrm{Q}_{9}=\mathrm{M}_{9}\left(\mathrm{~h}_{9 \mathrm{i}}-\mathrm{h}_{9 \mathrm{e}}\right) \\
& \mathrm{h}_{9 \mathrm{i}}=2762.33 \exp \left(0.000695^{\star} \mathrm{P}_{9}\right) \\
& \mathrm{S}_{9 \mathrm{i}}=6.799 \exp \left(-0.003573^{*} \mathrm{P}_{9}\right) \\
& h_{9 e}=660.354 \exp \left(0.016394^{*} P_{9}\right) \\
& \mathrm{S}_{9_{\mathrm{e}}}=1.93564 \exp \left(0.01187^{*} \mathrm{P}_{9}\right) \\
& 14 \leq \mathrm{P}_{9} \leq 17 \text { bar, } \quad 3 \leq \mathrm{M}_{9} \leq 3.6 \mathrm{t} / \mathrm{h}, \quad, \quad 6.5 \leq \mathrm{M}_{\mathrm{a}} \leq 6.909 \mathrm{~kg} / \mathrm{s} \text { and } \\
& 63 \leq \eta_{9} \leq 100 \% \text {, }
\end{aligned}
$$

\section{Subject to}

\subsection{Process-Brine Heater (PBH11):}

In Fig. 7, the modeling system for the process-brine heater ( $\mathrm{PBH} 11)$ is presented. This model shows the product cost of process-brine heater depending on operating parameters $\left(T_{11}, P_{11}, M_{11}, M b\right.$ and $\eta_{11}$ ) and economic parameters (cs and ca). Minimization of the product cost of the process-brine heater ( $\mathrm{PBH} 11)$ is selected as the optimization objective function:- 

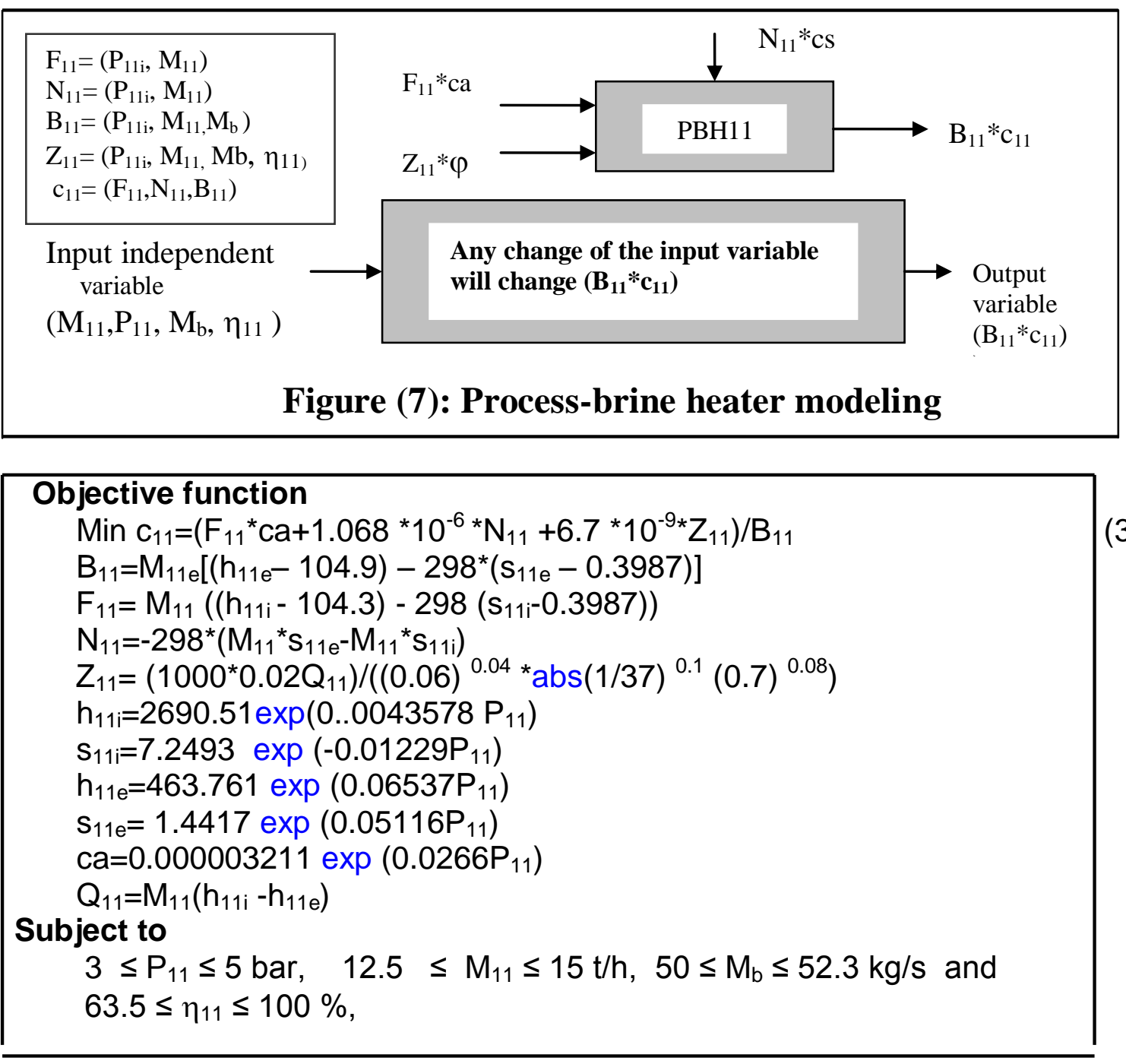

\section{Results of Case Study:}

Thermoeconomic optimization of the co-generation plant has been performed for the design operating conditions of the plant.

\section{1 Design Conditions and Data of Co-Generation Plant:}

The flow diagram for this case study (design conditions) is shown in Fig.1. The maximum steam generated from the boiler and the net electric power are $35 \mathrm{t} / \mathrm{h}$ and $4.15 \mathrm{MW}$, respectively. A process steam flow rate of $14.184 \mathrm{t} / \mathrm{h}$ is used for the brine heating.

\subsection{Results and Discussion:}

The co-generation plant has been analyzed using thermoeconomic analysis based on productive structure at different operating parameters. The optimization problem has been solved for the parameter values given in Table 3. The optimum values of each variable was calculated, minimizing the production cost of the main components represented by that variable. Thermodynamic optimization requires $\eta_{1}, \eta_{2}, \eta_{6}$ and $\eta_{9}$ to take the maximum possible value, ideally to be equal to 1 . Since this is impossible, these variables are set equal to their optimum values of the thermoeconomic optimization. Also, the comparison between the initial and optimum efficiencies is presented in Fig. 9. This figure shows that the boiler efficiency increases from $81 \%$ for the initial (normal) operating conditions to $90.48 \%$ for the 
optimum operating conditions. On they other hand, the process-air heater (PAH9) efficiency increases from $63.5 \%$ for the initial (normal) operating conditions to $64.5 \%$ for the optimum operating conditions.

Table 3 shows some of the most significant flow streams in design and optimum conditions using the thermoeconmic optimization process. Note that the optimum product cost in steam system decreased with respect to the initial values without the condensate pump product cost $\left(c_{4}\right)$ and desuperheater product cost $\left(c_{10}\right)$. As shown in Table 4 , the comparison between the initial and optimum product costs of the main components for the steam system is presented. This table shows that the total product costs decreases from $86.63^{*} 10^{-6} \$ / \mathrm{kJ}$ for the initial (normal) operating conditions to $76.64^{*} 10^{-6} \$ / \mathrm{kJ}$ for the optimum operating conditions. Moreover, approximately $11.53 \%$ of the total product cost was saved according to the optimization results in the normal operating conditions. The results agree with the results of the previous studies [3]. This is may be due to the lower the cost of fuel and, consequently, lower the interior cost and negentropy cost of the main components for the system.

Table (3): Optimization results of the local variables for process- steam plant

\begin{tabular}{|c|c|c|}
\hline Variable & Initial & Optimum \\
\hline $\begin{array}{ll}M_{f} & (\mathrm{~kg} / \mathrm{s})\end{array}$ & 0.4809 & 0.45 \\
\hline $\begin{array}{ll}M_{1} & (\mathrm{~kg} / \mathrm{s})\end{array}$ & 9.444 & 9.444 \\
\hline$T_{1}$ & 460 & 470 \\
\hline$P_{1} \quad$ (bar) & 60 & 65 \\
\hline$\eta_{1} \quad(\%)$ & 83.8 & 90.48 \\
\hline$M_{2 i} \quad(\mathrm{~kg} / \mathrm{s})$ & 8.055 & 8.611 \\
\hline$\eta_{2} \quad(\%)$ & 75.58 & 84.8 \\
\hline$M_{3 i}(\mathrm{~kg} / \mathrm{s})$ & 3.333 & 3.194 \\
\hline $\mathrm{T}_{6 \mathrm{e}} \quad\left({ }^{\circ} \mathrm{C}\right)$ & 133 & 135 \\
\hline$\eta_{6} \quad(\%)$ & 93.13 & 93.18 \\
\hline $\begin{array}{ll}M_{9} & (\mathrm{~kg} / \mathrm{s})\end{array}$ & 0.889 & 0.8333 \\
\hline$M_{a}(\mathrm{~kg} / \mathrm{s})$ & 6.909 & 6.907 \\
\hline$P_{9}$ (bar) & 16 & 16 \\
\hline $\mathrm{T}_{10 \mathrm{i}}\left({ }^{\circ} \mathrm{C}\right)$ & 190 & 200 \\
\hline$\eta_{9} \quad(\%)$ & 63 & 64.5 \\
\hline$M_{b}(\mathrm{~kg} / \mathrm{s})$ & 52.3 & 50.697 \\
\hline$P_{11}$ (bar) & 5 & 5 \\
\hline$M_{11} \quad(\mathrm{~kg} / \mathrm{s})$ & 3.61 & 3.47 \\
\hline$\eta_{11} \quad(\%)$ & 63.5 & 63.9 \\
\hline $\mathrm{T}_{5 \mathrm{i}}\left({ }^{\circ} \mathrm{C}\right)$ & 190 & 200 \\
\hline
\end{tabular}

From Fig. 8, the product cost of the process-air heater and process-brine heater decreases from $18.51^{*} 10^{-6} \$ / \mathrm{kJ} \& 26.46^{*} 10^{-6} \$ / \mathrm{kJ}$ for the initial (normal) operating conditions to $18.09^{*} 10^{-6} \$ / \mathrm{kJ} \& 20.18^{*} 10^{-6} \$ / \mathrm{kJ}$, respectively, for the optimum operating conditions. This may be due to the increase of the efficiency for the process-air heater and process-brine heater. From Fig. 10, the results agree with the results of the previous studies [2]. 


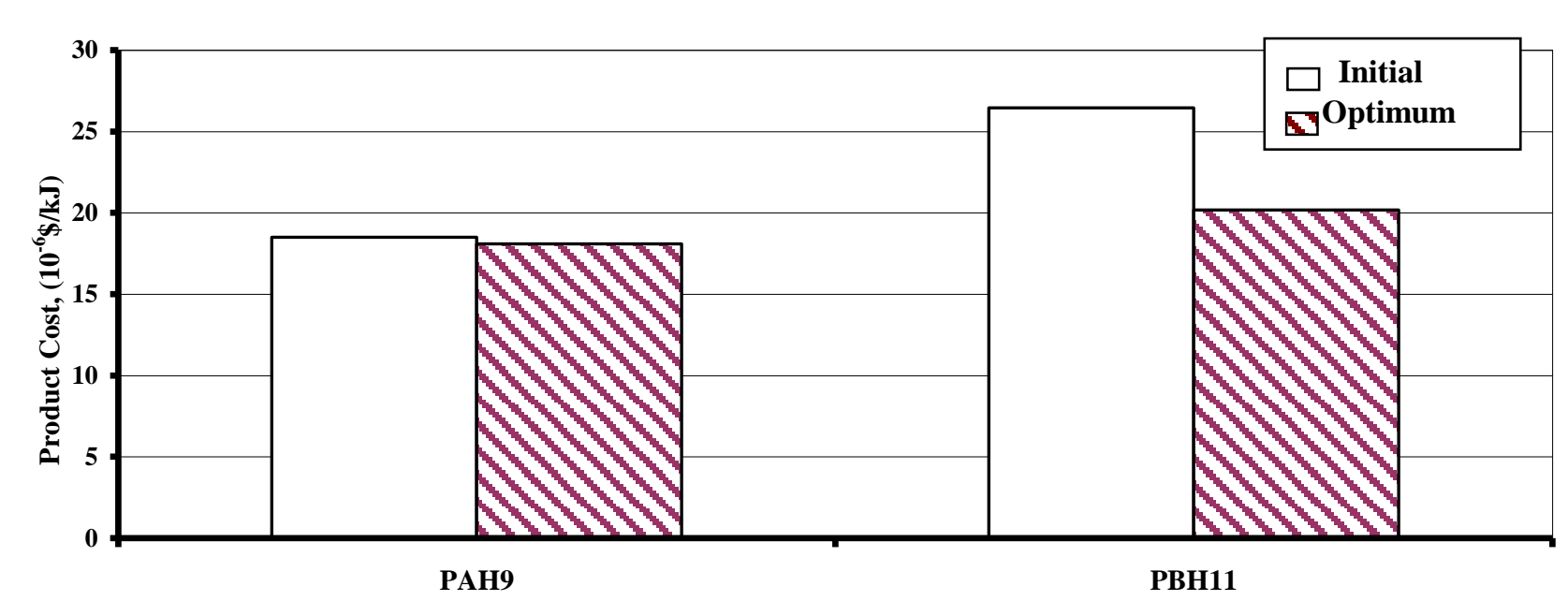

Figure( 8) : Comparison between initial and optimum product costs for process-air heater and process-brine heater .

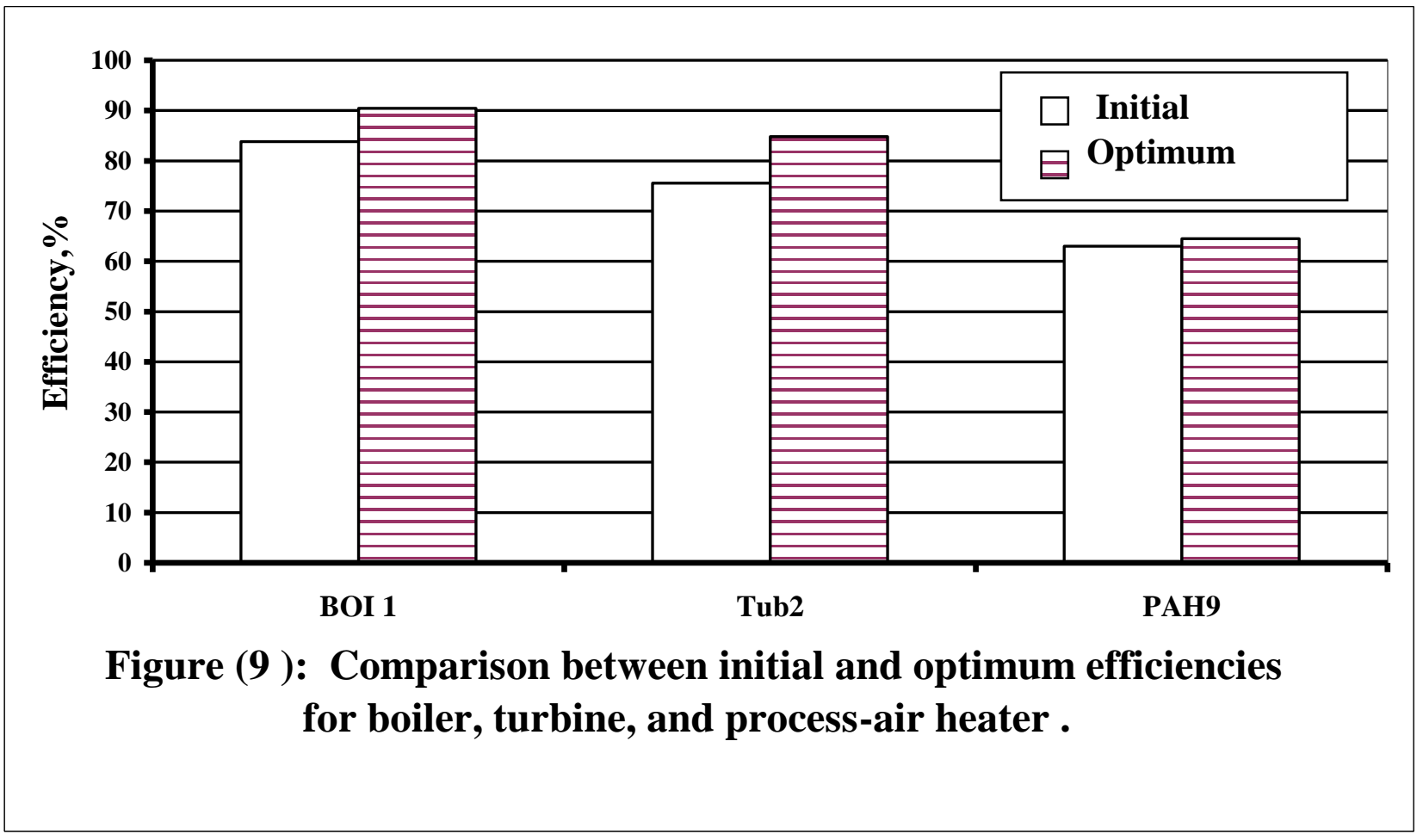




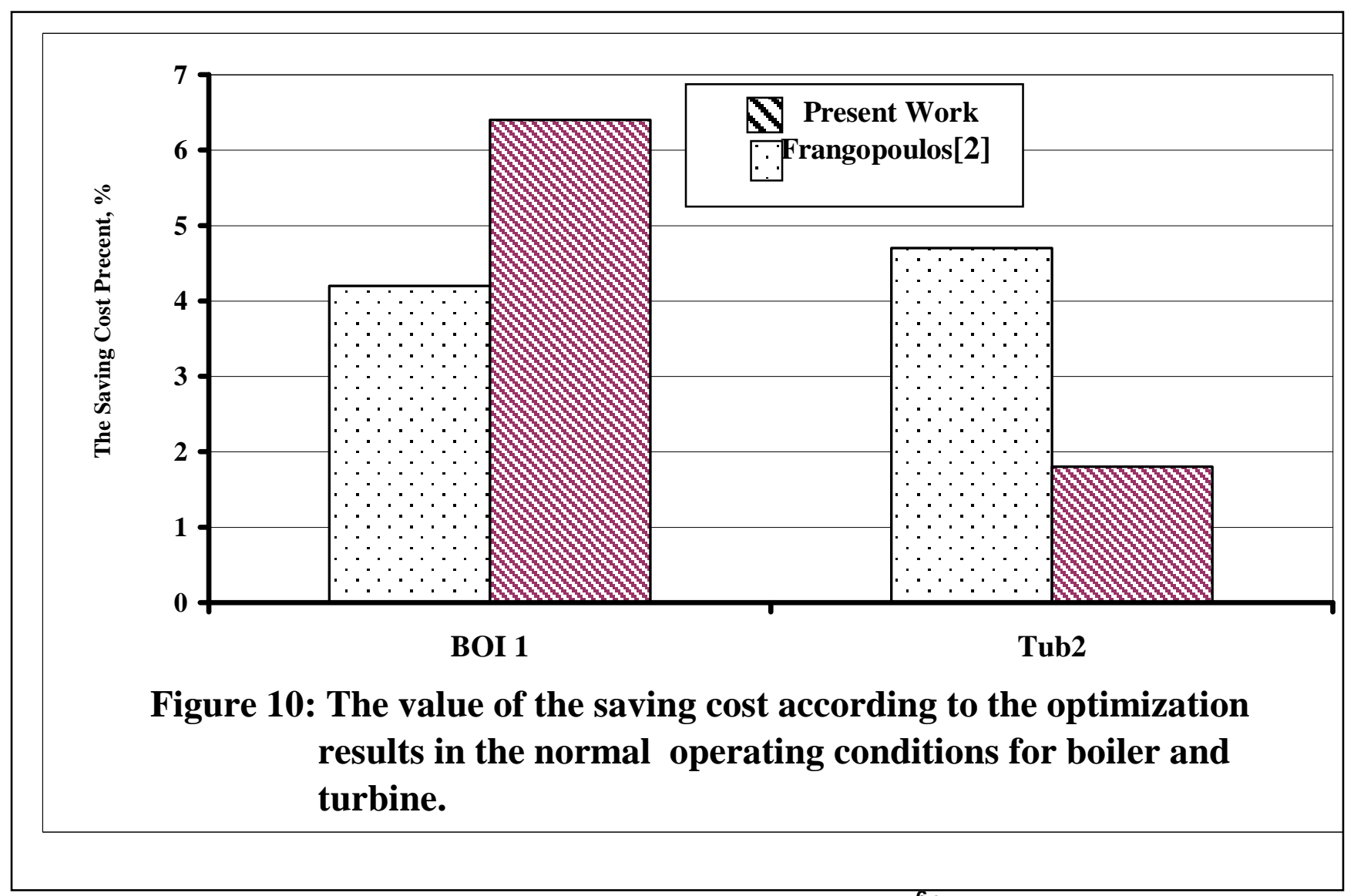

Table (4): Values of product costs at the optimum point $\left(10^{-6} \$ / \mathrm{kJ}\right)$ for co- generation plant .

\begin{tabular}{|c|c|c|c|c|}
\hline $\begin{array}{r}\text { Product } \\
\text { Cost }\end{array}$ & Initial & Optimum & $\begin{array}{r}\text { Variance } \\
\text { (Initial - Optimum) } \\
\end{array}$ & $\begin{array}{r}\text { Variance \% } \\
\left(10{ }^{*} \text { Variance/ Initial) }\right. \\
\end{array}$ \\
\hline$\overline{c_{1}}$ & 3.661 & 3.597 & 0.064 & 1.748 \\
\hline$c_{2}$ & 10.08 & 8.83 & 1.25 & 17.659 \\
\hline$c_{3}$ & 0.7508 & 0.7325 & 0.0183 & 2.437 \\
\hline$c_{4}$ & 1.221 & 1.43 & -0.209 & -17.1 \\
\hline$c_{5}$ & 6.41 & 5.324 & 1.086 & 16.94 \\
\hline$c_{6}$ & 2.444 & 2.12 & 0.324 & 13.26 \\
\hline$C_{7}$ & 4.388 & 3.728 & 0.66 & 15.04 \\
\hline$C_{8}$ & 3.056 & 2.973 & 0.083 & 2.72 \\
\hline$C_{9}$ & 18.51 & 18.09 & 0.42 & 2.27 \\
\hline$c_{10}$ & 3.788 & 3.972 & -0.184 & -4.86 \\
\hline$c_{11}$ & 26.46 & 20.18 & 6.28 & 23.73 \\
\hline$c_{12}$ & 5.035 & 4.92 & 0.115 & 2.28 \\
\hline$c_{13}$ & 0.8323 & 0.75121 & 0.08109 & 9.74 \\
\hline Total cost & 86.63 & 76.64 & 9.99 & 11.53 \\
\hline
\end{tabular}

\section{CONCLUSIONS:}

Optimization mathematical models of the main components for the steam system are carried out. Such models can be used to solve the steam system problems in order to achieve the optimization of the system operation. The solution methodologies for optimization 
mathematical models adopted are based on the quadratic algorithm.

The optimum values for operating parameters of the co-generation plant are investigated. The results show that the boiler efficiency increases from $81 \%$ for the initial (normal) operating conditions to $90.48 \%$ for the optimum once. On the other hand, the process-air heater efficiency increases from $63 \%$ to $64.5 \%$ for the optimum operating conditions. Moreover, as a global result, about $11.53 \%$ of the total product cost for all components of the plant when using optimum operating conditions other than normal once. As a result of the optimization for the steam system at different operating and economic parameters, the following recommendations could be outlined:

1- $\quad$ The optimum operating conditions for boiler are steam pressure 65 bar and steam temperature $4700^{\mathrm{C}}$.

2- $\quad$ The optimum operating conditions for process-brine heater (PBH11) are steam pressure 16 bar and steam mass flow rate $0.83 \mathrm{~kg} / \mathrm{s}$.

3- $\quad$ The optimum operating conditions for process-air heater (PAH9) are steam pressure 5 bar and steam mass flow rate $3.47 \mathrm{~kg} / \mathrm{s}$.

4- The optimum operating conditions for turbine are inlet steam mass flow rate $8.611 \mathrm{~kg} / \mathrm{s}$ and exhaust mass flow rate $3.194 \mathrm{~kg} / \mathrm{s}$.

\section{Acknowledgements}

The author wishes to express his thanks to the staff members of the Egyptian Salts \& Minerals Company (Emisal), El-Fayom, Egypt, for their support during carrying out this work.

Nomenclature

\begin{tabular}{|c|c|c|c|}
\hline B & Exergy rate, $\mathrm{kW}$ & $T$ & Temperature, $\mathrm{K}$ or ${ }^{\circ} \mathrm{C}$ \\
\hline $\mathrm{c}$ & Cost of product, $\$ / \mathrm{kJ}$ & \begin{tabular}{l|l} 
TTD & The
\end{tabular} & $\begin{array}{r}\text { temperature } \\
\text { difference, }{ }^{\circ} \mathrm{C}\end{array}$ \\
\hline $\mathrm{ca}$ & Cost of junction product, $\$ / \mathrm{kJ}$ & $\mathrm{V}$ & Velocity, $\mathrm{m} / \mathrm{s}$ \\
\hline $\mathrm{cb}$ & Cost of electric power, $\$ / \mathrm{kJ}$ & $\mathrm{W}_{\mathrm{T}}$ & Power of turbine, $\mathrm{kW}$ \\
\hline cs & Cost of negentropy flow, $\$ / \mathrm{kJ}$ & $W_{P}$ & Power of pump, kW \\
\hline$C_{f}$ & Cost of fuel, $\$ / \mathrm{kJ}$ & & Greek Symbols \\
\hline $\mathrm{C}$ & Chemical exergy of fuel, $\mathrm{kW}$ & $\varphi$ & The amortization factor \\
\hline $\mathrm{e}$ & Parametric efficiency & $\Phi$ & The maintenance factor \\
\hline$F$ & exergy flow, $\mathrm{kW}$ & $\eta_{\mathrm{r}}$ & Reference efficiency \\
\hline FCR & Annual fixed charge rate percent & $\$$ & Dollars \\
\hline$g$ & Correction factor & Subscripts: & \\
\hline$g_{\eta}$ & Correction factor of efficiency & $1,2 . .13$ & Thermodynamic states \\
\hline$g_{p}$ & Correction factor of pressure & & B \\
\hline$g_{T}$ & Correction factor of temperature & $\mathrm{BOI}$ & Boiler \\
\hline $\mathrm{h}$ & Specific enthalpy, kJ/kg & CND & Condenser \\
\hline $\mathrm{M}$ & Mass flow rate, $\mathrm{t} / \mathrm{h}$ or $\mathrm{kg} / \mathrm{s}$ & CNT & Condensate tank \\
\hline$P$ & Pressure, bar & Desup & Desuperheater \\
\hline$\Delta \mathrm{P}_{\mathrm{s}}$ & The losses inside shell, bar & $\$$ & Dollars \\
\hline
\end{tabular}




\begin{tabular}{|c|c|c|c|}
\hline$\Delta \mathrm{P}_{\mathrm{t}}$ & The losses inside tube, bar & $E$ & Exit \\
\hline $\mathrm{S}$ & Negentropy, & $\mathrm{F}$ & Fuel \\
\hline $\mathrm{N}$ & Negentropy flow, & FWP & Feed-water pump \\
\hline $\mathrm{s}$ & Specific entropy, $\mathrm{kJ} / \mathrm{kg} \mathrm{K}$ & PAH & Process-air heater \\
\hline $\mathrm{V}$ & Volume flow rate, $\mathrm{m}^{3} / \mathrm{s}$ & PBH & Process-brine \\
\hline$\Delta \mathrm{P}_{\mathrm{s}}$ & The losses inside shell, bar & $\mathrm{O}$ & Surroundings \\
\hline$\Delta \mathrm{P}_{\mathrm{t}}$ & The losses inside tube, bar & St & Steam \\
\hline$\dot{Y}$ & Rate output from the power, $\mathrm{kW}$ & Thv & Throttling \\
\hline Z & Capital cost of device, $\$$ & Tub & Turbine \\
\hline$\dot{Z}$ & Capital cost rate of device, $\$ / \mathrm{s}$ & $\mathrm{W}$ & Water \\
\hline
\end{tabular}

\section{References}

1. Javier, U., Luis, S., and Antonio, V., " Thermoeconomic Optimization of a Dual-Purpose Power and Desalination Plant", Journal of Desalination, Vol. 136, pp. 147-158, 2000.

2. Frangopoulos, C., A., " Thermoeconomic Functional Analysis and Optimization", Journal of Energy, Vol. 12, No. 7, pp. 563-571, 1987.

3. Frangopoulos, C., A., " Methods of Energy Systems Optimization " Summer School, Gliwice, Poland, 2003.

4. Goff, P., and Hornut, J., M., " Exergy Analysis and Exergy-Economic Optimization of Industrial Processes", Institute Franca Petroleum, Vol. 53, pp. 99-102, 1998.

5. Chao, Z.,Yan.W, Chuguang. Z.,Xinsheng, L., "Exergy Cost Analysis of a Coal Fired Power Plant Based on Structural Theory of Thermoeconomics", Journal of Energy Conversion and Management, Vol. 47, pp. 817-843, 2006

6. El-Dib,A.F., Gomaa, A.H., and Afefy, I.H., " Thermoeconomic Analysis of Co-Generation plant Based on Productive Structure Technique "Engineering Research Journal, Vol. 114, PP. 33-46, 2007

7. Agazzani, A., and Massardo, A., F., "A Tool for Thermoeconomic Analysis and Optimization of Gas, Steam, and, Combined Plants", Journal of Engineering for Gas Turbines and Power, Vol. 119, pp. 188-892, 1997.

8. Verlo, A., Lozano, M., A., and Munoz, M., "A General Theory of Exergy on Exregetic Cost" Journal of ASME, AES, Vol. 2, pp.1-21, 1986.

9. Chao, Z.,Yan.W, Chuguang. Z.,Xinsheng, L., "Exergy Cost Analysis of A Coal Fired Power Plant Based on Structural Theory of Thermoeconomics", Journal of Energy Conversion and Management, Vol. 47, pp. 817-843,. 2006

10. Frangopoulos, C., A., " Optimal Synthesis and Operation of Thermal System by the Thermoeconomic Functional Approach", Journal of Engineering Gas Turbine and Power, Vol. 114, pp. 707-714, 1992.

11. Silveira, J., L. and Tuna, C., E., " Thermoeconomic Analysis Method for Optimization of Combined Heat and Power Systems- Part II", Journal of Progress in Energy and 
Proceeding of the 14th AMME Conference, 25 -27 May 2010

Combustion Science, Vol. 30, pp. 673-678, 2004.

Table (2): Rule base for the position controller

\begin{tabular}{|l|l|l|l|l|l|l|l|}
\hline e & NB & NM & NS & ZE & PS & PM & PB \\
\hline
\end{tabular}




\begin{tabular}{|l|l|l|l|l|l|l|l||}
\hline ce & & & & & & & \\
\hline NB & NB & NB & NB & NB & NM & NS & ZE \\
\hline NM & NB & NB & NB & NM & NS & ZE & PS \\
\hline NS & NB & NB & NM & NS & ZE & PS & PM \\
\hline ZE & NB & NM & NS & ZE & PS & PM & PB \\
\hline PS & NM & NS & ZE & PS & PM & PB & PB \\
\hline PM & NS & ZE & PS & PM & PB & PB & PB \\
\hline PB & ZE & PS & PM & PB & PB & PB & PB \\
\hline
\end{tabular}

\section{Conclusions:}

This paper presents the effect of damping constant and rotor inertia constant of the machines on the behavior of electromechanical wave propagation in a one-dimensional ring power system. The analyzed system is continuum, and it is discretized for simplicity of analysis. From the simulation results, it is clear that the higher oscillatory wave vanishes with the increase of damping constant and it suppresses the disturbance wave from its propagation through the entire network. Also, the increase of rotor inertia constant leads to the electromechanical wave propagation velocity decrease.

\section{References:}

[15] J. S. Thorp, C. E. Seyler and A. G. Phadke, Electromechanical Wave Propagation in Large Electric Power Systems, IEEE Transactions on Circuits and Systems I: Fundamental Theory and Applications, Vol. 45, No. 6, P. 614-622, June 1998.

\section{Nomenclatures:}

... Power angle

... Rotor speed

a ... Acceleration

b ... Conductance

\section{Notes:}

To write your manuscript articles, you just need to use the previous template and fill in the spaces (inside the table columns) of the previous manuscript model.

Also, you need to take care of the following:

1- $\quad$ The manuscript is delivered in both of Microsoft-Word file (Word 2002 or before) and .pdf file.

2- $\quad$ All the manuscript articles have a single line spacing paragraph format with (normal) style. 
3- $\quad$ All the manuscript articles have a font size (14) of type (Times New Roman) with (different) font styles according to the position of the manuscript.

4- $\quad$ The title has a font size (16) of type (Times New Roman - Bold).

5- $\quad$ Margins are: top $=2 \mathrm{~cm}$, bottom $=2 \mathrm{~cm}$, right $=2 \mathrm{~cm}$, left $=2 \mathrm{~cm}$, header $=1.75$ $\mathrm{cm}$ and footer $=0.75 \mathrm{~cm}$.

6- $\quad$ Let the paper code and paper numbering (EE014 - 1) as it is in this template; the committee will put it.

7- Equation fonts are $(14,8,6,14,12)$ with regular style (neither bold nor italic symbols).

MAX. NO. OF PAGES $=10$ 